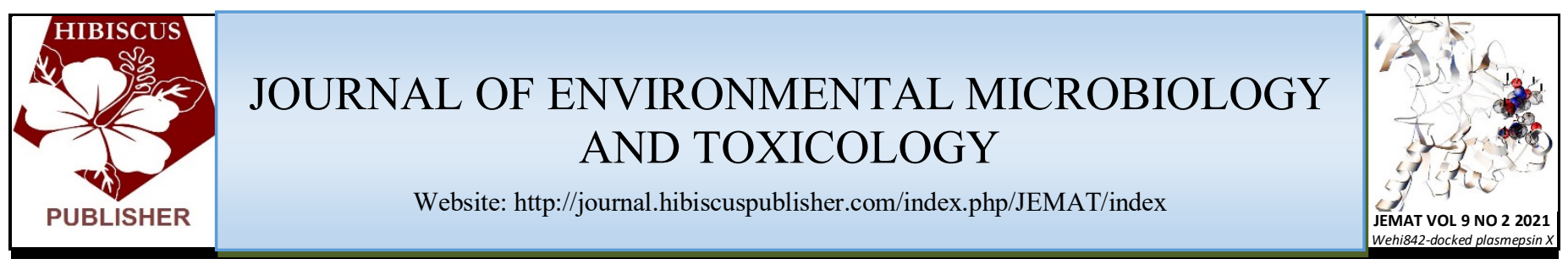

\title{
The Effect of High Dosage of Codeine-Containing Cough Syrup on Renal Function on Albino Rats
}

\author{
Ramlatu Musa Adam ${ }^{1 *}$, Aishatu Bello ${ }^{1}$, Jalil Idi James ${ }^{1}$, Alhassan Ahmad Siddan ${ }^{1}$ and Abubakar Aisami ${ }^{1}$ \\ ${ }^{1}$ Biochemistry Department, Gombe State University, P.M.B 127, Tudun Wada, Gombe, Nigeria.
}

\author{
*Corresponding author: \\ Ramlatu Musa Adam, \\ Biochemistry Department, \\ Gombe State University, \\ P.M.B 127, \\ Tudun Wada, \\ Gombe, \\ Nigeria. \\ Email: ramlaadam2016@gmail.com
}

\section{HISTORY \\ Received: $15^{\text {th }}$ Oct 2021 \\ Received in revised form: $29^{\text {th }}$ Nov 2021 Accepted: $20^{\text {th }}$ Dec 2021}

\section{KEYWORDS}

Renal functions

Albino rat

Codein

Kidney toxicity

\begin{abstract}
Codeine-containing cough syrup (CCS) is one of the most abused drugs in the world especially among the youths. However, there is need to study the nephrotoxic effect associated with oral administration of the drug and to ascertain its effect on the kidney. Consequently, understanding the renal abnormalities in chronic use of CCS will be crucial for effective development of interventions. This study assessed the nephrotoxic effect associated with oral administration of codeine-containing cough syrup (Tutolin with Codeine) in albino rats, using the level of creatinine, urea, sodium, potassium and chloride ions as biomarker in the serum of albino rats. The rats were administered orally with Tutolin and Codeine at a dose of $80 \mathrm{mg} / \mathrm{kg}, 160 \mathrm{mg} / \mathrm{kg}$, $240 \mathrm{mg} / \mathrm{kg}$ and $320 \mathrm{mg} / \mathrm{kg}$ body weight. After three weeks of oral administration of the syrup to all the groups, there was no difference $(P>0.05)$ in the levels of sodium ion, chloride ion and creatinine among all the study groups and levels of urea and potassium ion in the group administered with $80 \mathrm{mg} / \mathrm{kg}, 160 \mathrm{mg} / \mathrm{kg}$ and $240 \mathrm{mg} / \mathrm{kg}$ body weight of tutolin with codeine compared with the control. After three weeks of oral administration of $80 \mathrm{mg} / \mathrm{kg}, 160 \mathrm{mg} / \mathrm{kg}, 240$ $\mathrm{mg} / \mathrm{kg}$ and $320 \mathrm{mg} / \mathrm{kg}$ body weight tutolin with codeine cough syrup, urea and potassium ion concentrations were higher $(\mathrm{p}<0.05)$ in group given $320 \mathrm{mg} / \mathrm{kg}$ body weight of tutolin with codeine cough syrup compared with the control. This suggests that at higher doses, tutolin with codeine containing cough syrup may have effect on the kidney.
\end{abstract}

\section{INTRODUCTION}

In a number of mammals, the kidneys located behind the abdomen on the sides of the vertebral column are important excretory organs. Depending on the sex, age and body surface area, the weight of the kidneys varies [1,2]. The kidneys regulate body fluids and electrolyte, blood $\mathrm{pH}$ and its pressure, hormone and also play roles in metabolism [3]. The kidney also serves as the route of excretion of foreign (xenobiotic) materials and possesses enzymes that can convert those xenobiotics to harmless substances through the process of biotransformation [4]. The foreign substances are found in high concentrations at the proximal tubules after the process of ultrafiltration and reabsorption of the blood flowing through the kidneys. Xenobiotic-metabolizing enzymes activities such as mixedfunction oxidases are present in the proximal tubules and the activity varies along various segments of the nephron [5]. The toxic effect of drugs on the kidney is always encountered in clinical medicine; this causes acute kidney injury (AKI) which is very expensive to treat [6]. Drugs can cause nephrotoxicity by modifying intra-glomeular hemodynamics and reducing GFR
(ACEI, angiotensin-converting enzyme blockers [ARBs], NSAID, cyclosporine, and tacrolimus) [5]. Certain antibiotics and drugs used in the treatment of uric acid and calcium phosphate deposition causes crystal nephropathy [7]. Statins and alcohol may bring about rhabdomyolysis due to the toxic effect on myocyte function [8].

Drugs most often associated with thrombotic microangiopathy include antiplatelet agents (e.g., cyclosporine, mitomycinC, and quinine $[9,10]$. Drugs associated with tubular cell toxicity and acute interstitial nephropathy include aminoglycosides, amphotericin B, cisplatin, beta lactams, quinolones, rifampin, sulfonamides, vancomycin, acyclovir, and contrast agents [11]. These agents induce renal tubular cell injury by impairing mitochondrial function and interfering with tubular transport and increasing oxidative stress and free radicals [11]. Chronic use of acetaminophen, aspirin, diuretics and lithium is associated with chronic interstitial nephritis leading to fibrosis and renal scarring [12]. Opium (Papaver somniferum) has been historically known to be used as an aphrodisiac [13]. Codeine, a derivative of opium, is considered less potent in term of analgesic 
and sedative effects than opium. It has been used for treating cough, diarrhoea and pain but has additive potential too [13]. The growing interest in the use of Over the counter (OTC) opioid like codeine-containing cough syrup for both recreational and therapeutic conditions demand information on the toxicity risk assessment of the cough syrup (Codeine-containing cough syrup) preparation used in the management of cough related diseases. It is in the light of this that the study was carried out to provide facts on the safety or harmfulness of codeine-containing cough syrup. In addition, there is need for research work that will give a guide on the doses that may alter kidney functions.

\section{MATERIALS AND METHOD}

\section{Reagents}

The analytical grade reagents obtained from Biosystem Reagents and laboratories, Costa Bravo, Barcelona, Spain and Teco Diagnostics Anaheim, USA were used for the analysis. The reagent used includes $\mathrm{Na}^{+}, \mathrm{Cl}^{-}, \mathrm{K}^{+}$ions, Urea and Creatinine kits.

\section{Experimental Animals}

Twenty (20) albino rats of both sexes (body weight ranging from 84 to $232 \mathrm{~g}$ ) were gotten from Plateau state at the National Research Institute, Vom. The rats were left to get use to the new environment and fed with grower's mash and water at Gombe state university animal house. They were then shared into five groups of 4 rats each. Group I, II, III, IV were the study group and were given the various concentration of the syrup while the fifth group served as the control group. Table 1 shows the summary of the experimental design.

Table 1. Experimental design summary.

\begin{tabular}{|c|c|c|c|c|}
\hline Groups & $\begin{array}{l}\text { Number of } \\
\text { Animals }\end{array}$ & $\begin{array}{l}\text { Average } \\
\text { weight of rats } \\
\text { (g) }\end{array}$ & $\begin{array}{l}\text { Doses in } \\
(\mathrm{mg} / \mathrm{Kg})\end{array}$ & $\begin{array}{l}\text { Volume of } \\
\text { cough syrup } \\
\text { in }(\mathrm{ml})\end{array}$ \\
\hline Control & 4 & 170.38 & - & - \\
\hline Group I & 4 & 150.40 & 80 & 0.8 \\
\hline Group II & 4 & 164.00 & 160 & 1.6 \\
\hline Group III & 4 & 190.40 & 240 & 2.9 \\
\hline Group IV & 4 & 233.80 & 320 & 4.6 \\
\hline
\end{tabular}

\section{Blood samples Preparation}

After three weeks of oral administration of codeine-containing cough syrup, the rats were decapitated, and blood samples obtained in heparinized container. The blood was then spun at 3000rpm for 5 minutes and the serum collected in a specimen bottle. Sera samples gotten were analyzed for creatinine, urea, sodium ion, potassium ion, and chloride ion activities using standard methods.

\section{RESULTS}

The results of data given as mean \pm S.D of Urea, Creatinine and Electrolytes $\left(\mathrm{Na}^{+}, \mathrm{Cl}^{-}\right.$and $\left.\mathrm{K}^{+}\right)$shown in Tables 2 and Table 3 were analyzed by the student t-test.

There was a major increase $(\mathrm{P}<0.05)$ in the level of urea in the group that were given $320 \mathrm{mg} / \mathrm{Kg}$ body weight of tutolin with codeine cough syrup matched to the control (Table 2). In Table 3 , there was a marked increase $(\mathrm{P}<0.05)$ in potassium ion level matched to the control in the group given $320 \mathrm{mg} / \mathrm{kg}$ body weight of the cough syrup.

Table 2. Effect of tutolin with codeine cough syrup on serum urea and creatinine.

\begin{tabular}{lll}
\hline Groups/Dosage & Urea $(\mathrm{mmol} / \mathrm{L})$ & Creatinine $(\mu \mathrm{mol} / \mathrm{L})$ \\
\hline Control & $3.13 \pm 0.17$ & $47.25 \pm 6.85$ \\
$80 \mathrm{mg} / \mathrm{kg}$ & $3.00 \pm 0.12$ & $40.75 \pm 2.62$ \\
\hline
\end{tabular}

\begin{tabular}{rrr}
\hline $160 \mathrm{mg} / \mathrm{kg}$ & $3.10 \pm 0.23$ & $42.25 \pm 5.62$ \\
$240 \mathrm{mg} / \mathrm{kg}$ & $3.53 \pm 0.67$ & $43.00 \pm 4.69$ \\
$320 \mathrm{mg} / \mathrm{kg}$ & $3.50 \pm 0.08 *$ & $46.00 \pm 8.87$ \\
Value with superscript * is significantly dissimilar from control value at $\mathrm{P}<0.05$. \\
Values represent mean \pm S.D $(\mathrm{n}=4)$
\end{tabular}

Values represent mean \pm S.D $(\mathrm{n}=4)$

Table 3. Effect of tutolin with codeine cough syrup on electrolytes.

\begin{tabular}{clll}
\hline Groups/Dosage & $\mathrm{K}^{+}(\mathrm{mEq} / \mathrm{L})$ & $\mathrm{Cl}^{-}(\mathrm{mEq} / \mathrm{L})$ & $\mathrm{Na}^{+}(\mathrm{mEq} / \mathrm{L})$ \\
\hline Control & $5.78 \pm 0.36$ & $103.50 \pm 7.93$ & $141.00 \pm 4.76$ \\
$80 \mathrm{mg} / \mathrm{kg}$ & $5.30 \pm 0.48$ & $97.75 \pm 1.26$ & $137.75 \pm 0.96$ \\
$160 \mathrm{mg} / \mathrm{kg}$ & $6.10 \pm 0.46$ & $97.75 \pm 3.86$ & $138.00 \pm 4.24$ \\
$240 \mathrm{mg} / \mathrm{kg}$ & $5.80 \pm 064$ & $99.75 \pm 6.29$ & $139.00 \pm 5.60$ \\
$320 \mathrm{mg} / \mathrm{kg}$ & $7.10 \pm 0.14 *$ & $98.75 \pm 3.40$ & $139.00 \pm 2.94$ \\
Value with superscript * is significantly dissimilar from control value at $\mathrm{P}<0.05$. \\
Values denotes mean $\pm \mathrm{S} . \mathrm{D}(\mathrm{n}=4)$
\end{tabular}

\section{DISCUSSION}

From Table 2, the mean serum creatinine level of the control rats was found to be $(47.25 \pm 6.85 \mu \mathrm{mol} / \mathrm{L})$. There was no major difference $(\mathrm{p}>0.05)$ in the levels of creatinine matched to the control in groups given $80 \mathrm{mg} / \mathrm{kg}, 160 \mathrm{mg} / \mathrm{kg}, 240 \mathrm{mg} / \mathrm{kg}$ and $320 \mathrm{mg} / \mathrm{kg}$ body weight of tutolin with codeine cough syrup. This indicates that the kidney is functioning properly. Through the process of glomerular filtration, creatinine is removed from the urine and plasma via the tubules, excretion via urine is not reabsorbed extensively. High creatinine levels are only obtained when the level of kidney damage is extensive which shows renal failure [14].

From Table 2, the mean serum urea of control group was found to be $3.13 \pm 0.17 \mathrm{mmol} / \mathrm{L}$ which appeared to be within the reported normal range of $1.7-9.1 \mathrm{mmol} / \mathrm{L}$ [15]. Serum urea was found to be considerably higher $(P<0.05)$ than the control in group given $320 \mathrm{mg} / \mathrm{kg}$ body weight of tutolin with codeine cough syrup. This signifies that the oral administration of tutolin with codeine in higher doses might have possible nephrotoxic effect. Increase in serum urea may result from a lot of factors like diet and dehydration, but kidney damage is the sole factor that escalates serum creatinine level [16]. From the result of this study, high doses of tutolin with codeine cough syrup did not cause a reasonable increase in serum creatinine, the increase obtained in serum urea level may or may not be associated with nephrotoxicity. It has been reported that changes in blood urea are normally go hand in hand with variations in blood creatinine [14].

Urea is main product of protein breakdown; the increase seen in urea level shows impairment in the normal kidney function of the rats administered with $320 \mathrm{mg} / \mathrm{kg}$ body weight of tutolin with codeine cough syrup as the mechanism of getting rid of it from the blood might have been damaged. It may also be an indication of lack of proper functioning of the glomerular and tubules of the kidney [17]. It was found that there was no substantial difference $(\mathrm{P}>0.05)$ in the level of serum urea in groups administered with $80 \mathrm{mg} / \mathrm{kg}, 160 \mathrm{mg} / \mathrm{kg}$ and $240 \mathrm{mg} / \mathrm{kg}$ body weight of tutolin with codeine cough syrup.

From Table 3, the mean serum potassium ion concentration of the control was found to be $5.78 \pm 0.36 \mathrm{mEq} / \mathrm{L}$ which appeared to be within the reported normal range of $5.4-7.0 \mathrm{mEq} / \mathrm{L}[19]$.

Significant increase $(\mathrm{P}<0.05)$ in group given $320 \mathrm{mg} / \mathrm{kg}$ body weight of tutolin with codeine cough syrup was observed compared to the control, but the increase observed was not dose dependent since it is the only group seen with significant increase in serum potassium ion concentration. There are many causes of hyperkalaemia, these can be: kidney diseases and dehydration 
[18]. Also from Table 3, there was no substantial difference $(\mathrm{P}>0.05)$ in the level of potassium ion in groups given $80 \mathrm{mg} / \mathrm{kg}$, $160 \mathrm{mg} / \mathrm{kg}$, and $240 \mathrm{mg} / \mathrm{kg}$ body weight of tutolin with codeine cough syrup compared to the control.

From Table 3, the mean serum chloride ion concentration of the control rats was found to be $103.50 \pm 7.94 \mathrm{mEq} / \mathrm{L}$ which appeared to be within the reported normal range of 100-110 $\mathrm{mEq} / \mathrm{L}[19]$. There was no significant difference $(P>0.05)$ in the level of chloride ion in groups administered with $80 \mathrm{mg} / \mathrm{kg}, 160$ $\mathrm{mg} / \mathrm{kg}, 240 \mathrm{mg} / \mathrm{kg}$ and $320 \mathrm{mg} / \mathrm{kg}$ body weight of tutolin with codeine cough syrup compared to the control group. The mean serum sodium ion concentration of the control rats was found to be $141.00 \pm 4.76 \mathrm{mEq} / \mathrm{L}$ (Table 3), which appeared to be within the reported normal range of $143-156 \mathrm{mEq} / \mathrm{L}$ [19]. There was no significant difference $(\mathrm{P}>0.05)$ in the level of sodium ion in groups administered with $80 \mathrm{mg} / \mathrm{kg}, 160 \mathrm{mg} / \mathrm{kg}, 240 \mathrm{mg} / \mathrm{kg}$ and $320 \mathrm{mg} / \mathrm{kg}$ body weight of tutolin with codeine cough syrup compared to the control group.

\section{CONCLUSION}

The results of the study have shown that oral administration of tutolin with codeine cough syrup has effect on some of the biomarkers of kidney function. Results of the levels of urea and potassium ion showed that, there was kidney malfunction with the rats administered with $320 \mathrm{mg} / \mathrm{kg}$ body weight of tutolin with codeine cough syrup as the level of urea and potassium ion in that group rises above the control value.

\section{REFERENCES}

1. Haschek WM, Rousseaux CG, Wallig MA. Fundamentals of Toxicologic Pathology. Houston, TX: Gulf Professional Publishing. 2010.

2. Khan N, Hard GC, Alden CL. Kidney. Haschek and Rousseaux's Handbook of Toxicologic Pathology. California, United States: Academic Press; 2013.

3. Ettore B. Adverse effects of drugs on the kidney. Eur J Intern Med. 2015; 28: $1-8$.

4. Piyush B., Swapan K. C., Robert Y., Edward J. K. and Guangquing $\mathrm{X}$. Emerging kidney models to investigate Metabolism, Transport and Toxicity of Drugs and Xenobiotics. Drug Metab Dispos. 2018; 46 (11) 1692-1702.

5. Nigam SK, Wu W, Bush KT, Hoenig MP, Blantz RC, Bhatnagar V. Handling of drugs, metabolites, and uremic toxins by kidney proximal tubule drug transporters. Clin J Am Soc Nephrol. 2015; 10(11):2039-2049.

6. Schetz, M., Dasta, J., Goldstein, S. and Golper, T. Drug — Induced Acute Kidney lnjury. Curr. Opin. Intl. Care, 2009; 11(6): 555-565.

7. Davidson MB, Thakkar S, Hix JK, Bhandarkar ND, Wong A, Schreiber MJ. Pathophysiology, clinical consequences, and treatment of tumor lysis syndrome. Am J Med. 2004; 116:546-54

8. Huerta-Alardín AL, Varon J, Marik PE. Bench-tobedside review rhabdomyolysis - an overview for clinicians. Crit Care. 2005;9:158-69.

9. Pisoni R, Ruggenenti P, Remuzzi G. Drug induced thrombotic micro angiopathy: incidence, prevention and management. Drug Saf. 2001; 24:491-501.

10. Manor SM, Guillory GS, Jain SP. Clopidogrel-induced thrombotic thrombocytopenic purpura-hemolytic uremic syndrome after coronary artery stenting. Pharmacotherapy. 2004; 24:6647

11. Perazella MA. Drug-induced nephropathy: an update. Expert Opin Drug Saf. 2005;4:689-706.

12. Guo, X. Nzerue, C. How to Prevent, recognize, and treat druginduced nephrotoxicity. Cleve Clin J Med. 2002 Apr 1;69(4):28990

13. Anil S. S., Ratnakaran B. and Suresh N. A case report of over-thecounter codeine dependence as consequence of self-medication for premature ejaculation. J Family Med Prim. Care. 2017; 6:867-9

14. Delanaye P., Cavalier E. and Pottel H. Serum Creatinine: Not so simple. Clinical practice: review. Nephron 2017; 136: 302-308
15. Higgins C. Urea and creatinine concentration, the urea:creatinine ratio. Retrieved from www.acutecaretesting.org 2016

16. Cheesbrough, M. Clinical Chemistry Test In; District Laboratory Practice In Tropical Countries: Paint, I; Cheeshrough, M. (ed.) Cambridge University Press, Cambridge. Pp. 1998; 331 -363.

17. Wurochekke, A. U., Anthony, A. E. and Obidah, W. Biochemical Effect on the liver and Kidney of rats administered with aqueous stem bark extract of Xemenia Americana. Afr J Biotechnol. 2008; 7:2777 - 2780.

18. Fray, A.C.and Farrington K. "Management of Acute Renal Failure". Postgraduate Med. 2006; 182: $106-116$.

19. Johnson-Delany, C. Exotic Animal Comparison Medicine Handbook for Veterinarians. Lake Worth, FL. Zoological Education Network. 1996; 55. 